\title{
Multi-layered prevention and treatment of chronic inflammation, organ fibrosis and cancer associated with canonical WNT/ $\beta$-catenin signaling activation (Review)
}

\author{
MASARU KATOH \\ Department of Omics Network, National Cancer Center, Chuo Ward, Tokyo 104-0045, Japan
}

Received December 18, 2017; Accepted May 16, 2018

DOI: $10.3892 /$ ijmm.2018.3689

\begin{abstract}
CTNNB1 is an intracellular scaffold protein that interacts with adhesion molecules (E-cadherin/CDH1, N-cadherin/CDH2, VE-cadherin/CDH5 and $\alpha$-catenins), transmembrane-type mucins (MUC1/CD227 andMUC16/CA125), signaling regulators(APC,AXIN1,AXIN2 and NHERF1/EBP50) and epigenetic or transcriptional regulators (BCL9, BCL9L, CREBBP/CBP, EP300/p300, FOXM1, MED12, SMARCA4/BRG1 and TCF/LEF). Gain-of-function CTTNB1 mutations are detected in bladder cancer, colorectal cancer, gastric cancer, liver cancer, lung cancer, pancreatic cancer, prostate cancer and uterine cancer, whereas loss-of-function $C T N N B 1$ mutations are also detected in human cancer. ABCB1, ALDH1A1, ASCL2, ATF3, AXIN2, BAMBI, CCND1, CD44, CLDN1, CTLA4, DKK1, EDN1, EOMES, FGF18, FGF20, FZD7, IL10, JAG1, LEF1, LGR5, MITF, MSX1, MYC, NEUROD1, NKD1, NODAL, NOTCH2, NOTUM, NRCAM, OPN, PAX3, PPARD, PTGS2, RNF43, SNAII,SP5, TCF7,TERT, TNFRSF19, VEGFA and ZNRF3 are representative $\beta$-catenin target genes. $\beta$-catenin signaling is involved in myofibroblast activation and subsequent pulmonary fibrosis, in addition to other types of fibrosis. $\beta$-catenin and NF- $\mathrm{KB}$ signaling activation are involved in field cancerization in the stomach associated with Helicobacter pylori $(H$. pylori) infection and in the liver associated with hepatitis $\mathrm{C}$ virus (HCV) infection and other etiologies. $\beta$-catenin-targeted therapeutics are functionally classified into $\beta$-catenin inhibitors targeting upstream regulators (AZ1366, ETC-159, G007-LK, GNF6231, ipafricept, NVP-TNKS656, rosmantuzumab, vantictumab, WNT-C59, WNT974 and XAV939), $\beta$-catenin inhibitors targeting protein-protein interactions (CGP049090, CWP232228, E7386, ICG-001, LF3 and PRI-724), $\beta$-catenin inhibitors targeting epigenetic regulators (PKF118-310), $\beta$-catenin inhibitors targeting mediator
\end{abstract}

Correspondence to: Dr Masaru Katoh, Department of Omics Network, National Cancer Center, 5-1-1 Tsukiji, Chuo Ward, Tokyo 104-0045, Japan

E-mail: mkatoh-kkr@umin.ac.jp

Key words: cardiovascular fibrosis, immune evasion, FZD5, oncolytic adenovirus, porcupine, RSPO3, tankyrase, tumor microenvironment, TGF- $\beta$, WNT2B complexes (CCT251545 and cortistatin A) and $\beta$-catenin inhibitors targeting transmembrane-type transcriptional outputs, including CD44v6, FZD7 and LGR5. Eradicating H. pylori and $\mathrm{HCV}$ is the optimal approach for the first-line prevention of gastric cancer and hepatocellular carcinoma (HCC), respectively. However, $\beta$-catenin inhibitors may be applicable for the prevention of organ fibrosis, second-line HCC prevention and treating $\beta$-catenin-driven cancer. The multi-layered prevention and treatment strategy of $\beta$-catenin-related human diseases is necessary for the practice of personalized medicine and implementation of precision medicine.

\section{Contents}

1. Introduction

2. Gain- and loss-of-function $\beta$-catenin alterations in human cancer

3. Activation of $\beta$-catenin in chronic gastritis and gastric cancer associated with Helicobacter pylori infection

4. Activation of $\beta$-catenin in liver fibrosis and hepatocellular carcinoma

5. Activation of $\beta$-catenin in pulmonary fibrosis and lung cancer

6. Therapeutics targeting $\beta$-catenin for preventing organ fibrosis or treating cancer

7. Multi-layered prevention and treatment of $\beta$-catenin-related diseases

\section{Introduction}

The CTNNB1 gene encodes the intracellular scaffold protein $\beta$-catenin (1), which interacts with adhesion molecules (E-cadherin/CDH1, N-cadherin/CDH2, VE-cadherin/CDH5 and $\alpha$-catenins) $(2,3)$, transmembrane mucins (MUC1/CD227 and MUC16/CA125) (4,5), cytoplasmic signaling regulators (APC, AXIN1, AXIN2, BTRC/ $\beta$ TRCP1, BTRC2/ $\beta$ TRCP2 and NHERF1/EBP50) $(6,7)$, and nuclear transcriptional regulators (BCL9, BCL9L, CREBBP/CBP, EP300/p300, FOXM1, LEF1/TCF7L3, MED12, SMARCA4/BRG1, SPDEF, TCF7/TCF-1, TCF7L1/TCF-3 and TCF7L2/TCF-4) (8-10). Based on protein-protein interactions (PPIs), $\beta$-catenin is involved in cell-cell adhesion, cellular signaling and transcriptional regulation (Fig. 1A). 
$\beta$-catenin undergoes post-translational modifications, including acetylation, glycosylation, methylation, phosphorylation and ubiquitylation. Oncogenic tyrosine kinases phosphorylate $\beta$-catenin at Y654 to release $\beta$-catenin from cadherin complexes, whereas canonical WNT signals prevent the phosphorylation of $\beta$-catenin at S33, S37, T41 and S45 to release $\beta$-catenin from ubiquitylation-mediated degradation (1). The $\beta$-TRCP complex is involved in the poly-ubiquitylation of S33/S37/T41/S45-phosphorylated $\beta$-catenin and subsequent proteasome-mediated degradation $(9,11)$, whereas USP7 is involved in the de-ubiquitylation and stabilization of $\beta$-catenin (12). Stabilized $\beta$-catenin is translocated into the nucleus to activate the transcription of TCF/LEF target genes (Fig. 1B). The acetylation of $\beta$-catenin at K49 leads to transcriptional activation, whereas the methylation of $\beta$-catenin at K49 leads to transcriptional repression $(13,14)$. The functions of $\beta$-catenin are regulated by its localization, PPIs and stability based on post-translational modifications.

Representative $\beta$-catenin target genes (Fig. 1C) include ABCB1, ALDH1A1, ASCL2, ATF3, AXIN2, BAMBI, CCND1 (Cyclin D1), CD44, Claudin-1 (CLDN1), CTLA4, DKK1, EDN1, EOMES, FGF18, FGF20, FZD7, GBXI, IL10 (IL-10), Jagged-1 (JAG1), LEF1, LGR5, MITF, MSXI, MYC (c-Myc), NEUROD1, NKD1, NODAL, NOTCH2, NOTUM, NRCAM, osteopontin (OPN), PAX3, PPARD, PTGS2 (COX2), RNF43, SNAII (Snail), SP5, TCF7, TERT, TNFRSF19 (Troy), VEGFA (VEGF) and ZNRF3 (1,15-28). CTTTGATAT is the consensus DNA-binding motif of TCF-3, whereas CTCGCGAGA is the major DNA-binding motif of TCF-1 (29). By contrast, lysine acetyltransferases CBP and p300 are reported to differentially regulate $\beta$-catenin-dependent transcriptional programs in stem cells to propel them towards self-renewal and differentiation, respectively (30). $\beta$-catenin target genes are upregulated in a cell context-dependent manner based on the epigenetic status of their regulatory regions and availability of transcriptional regulators (1).

Inflammation is an immune response to repair tissue damage caused by infectious agents, environmental stimuli and endogenous irritants. The failure to resolve acute inflammation leads to chronic inflammation characterized by the continuous activation of macrophages and lymphocytes in the inflamed tissue microenvironment and elevated levels of the pro-inflammatory cytokines IL-1 $\beta$, IL-6, IL-17 and TNF- $\alpha(31,32)$. Chronic persistent inflammation then leads to the collapse of homeostatic interactions among epithelial cells, stromal cells and immune cells in the tissue microenvironment, which causes organ fibrosis through the myofibroblast-like transition of tissue-resident fibroblasts, stellate cells or bone marrow-derived fibrocytes, and the subsequent deposition of extracellular matrix (ECM) components, including collagen, fibronectin and hyaluronan (Fig. 2A).

$\beta$-catenin signaling dysregulation is involved in chronic inflammation, organ fibrosis, and various types of human cancer $(1,33)$. However, $\beta$-catenin-targeted therapy is not yet approved for the treatment of patients with $\beta$-catenin-related diseases. As $\beta$-catenin is an intracellular protein without intrinsic enzymatic activity, it is difficult to target $\beta$-catenin for drug development. In this review, gain- and loss-of-function $\beta$-catenin alterations in human cancer types are summarized, and the pathophysiology of $\beta$-catenin-related chronic inflammation and/or organ fibrosis are presented with emphases on carcinogenesis in the stomach, liver and lungs. Finally, the development of $\beta$-catenin inhibitors targeting its upstream regulators, PPIs and downstream effectors are reviewed.

\section{Gain- and loss-of-function $\beta$-catenin alterations in human cancer}

$\beta$-catenin-dependent transcription is aberrantly activated in human cancer due to gain-of-function mutations in the $C T N N B 1$ gene itself, in addition to genetic alterations in the APC, AXIN2, RNF43 and RSPO3 genes involved in the canonical WNT/ $\beta$-catenin signaling cascade, upregulation of canonical WNT ligands in the tumor microenvironment, or Y654 phosphorylation of $\beta$-catenin by oncogenic tyrosine kinases, including BCR-ABL1 fusion, FLT3-ITD mutation and overexpression of MET (34).

Missense mutations at or in-frame deletions around S33, S37, T41 and S45 in $\beta$-catenin give rise to gain-of-function $\beta$-catenin mutants that are resistant to ubiquitylation-mediated proteasomal degradation and induce the upregulation of oncogenic target genes, including $C C N D I$ and $M Y C$, in adrenocortical tumors, bladder cancer, colorectal cancer, gastric cancer, liver cancer, lung cancer, pancreatic cancer, prostate cancer and uterine cancer (35-40). Aberrant $\beta$-catenin-dependent transcriptional activation drives human carcinogenesis through the induction of cancer stem cell (CSC) features, bulk tumor proliferation and the epithelial-to-mesenchymal transition (EMT) in the solid tumors mentioned above.

By contrast, nonsense or frame-shift mutations in $\beta$-catenin, including R95*, K335fs, R449fs, E458fs, R474*, R535*, E571* and E642fs, also occur in human cancer, including gastric cancer and head and neck squamous cell carcinoma (37,41-43). In melanoma, decreased $\beta$-catenin not only promotes invasion and metastasis through disrupted cell-cell adhesion but also resistance to targeted therapy through MITF/APE1 axis repression $(44,45)$. Ctnnbl haploinsufficiency has been shown to promote aggressiveness and metastasis in a mouse model of HER2-positive basal breast cancer (46). $\beta$-catenin exerts not only oncogenic but also tumor-suppressor functions in a context-dependent manner.

$\beta$-catenin mutations are classified as i) gain-of-function mutations clustered at or around S33, S37, T41 and S45, ii) loss-of-function mutations due to nonsense or frame-shift mutations and iii) other mutations to be further characterized. In addition to these coding mutations, copy number gain (47) and regulatory mutations in the proximal promoter region (48) of the $C T N N B 1$ gene encoding $\beta$-catenin have been reported in prostate cancer and breast cancer, respectively. Owing to the pro- and anti-oncogenic roles of $\beta$-catenin, integrative omics analyses, including whole-genome sequencing, transcriptome and immunohistochemical analyses, are necessary to precisely prescribe $\beta$-catenin-targeted therapeutics in personalized or precision medicine in the future.

\section{Activation of $\boldsymbol{\beta}$-catenin in chronic gastritis and gastric cancer associated with Helicobacter pylori infection}

Helicobacter pylori (H.pylori) is a Gram-negative, helical rod-shaped microaerophilic bacterium that specifically 


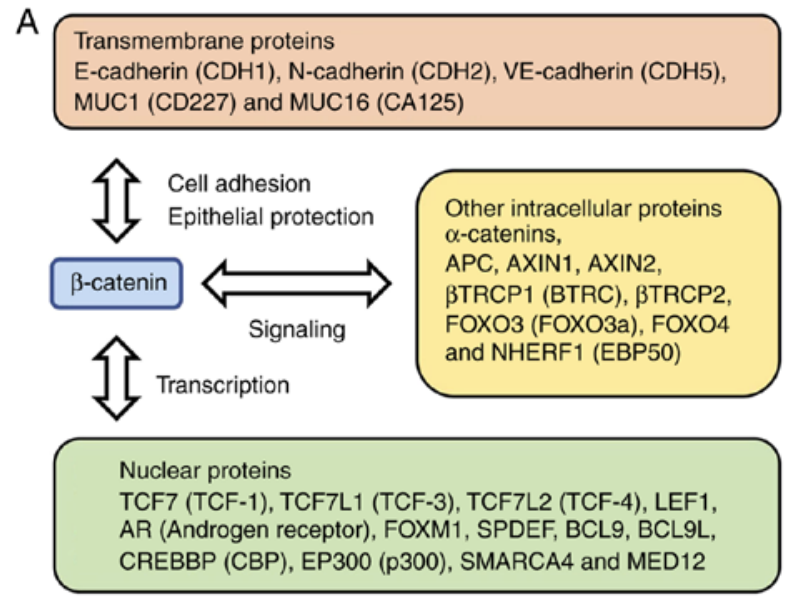

B
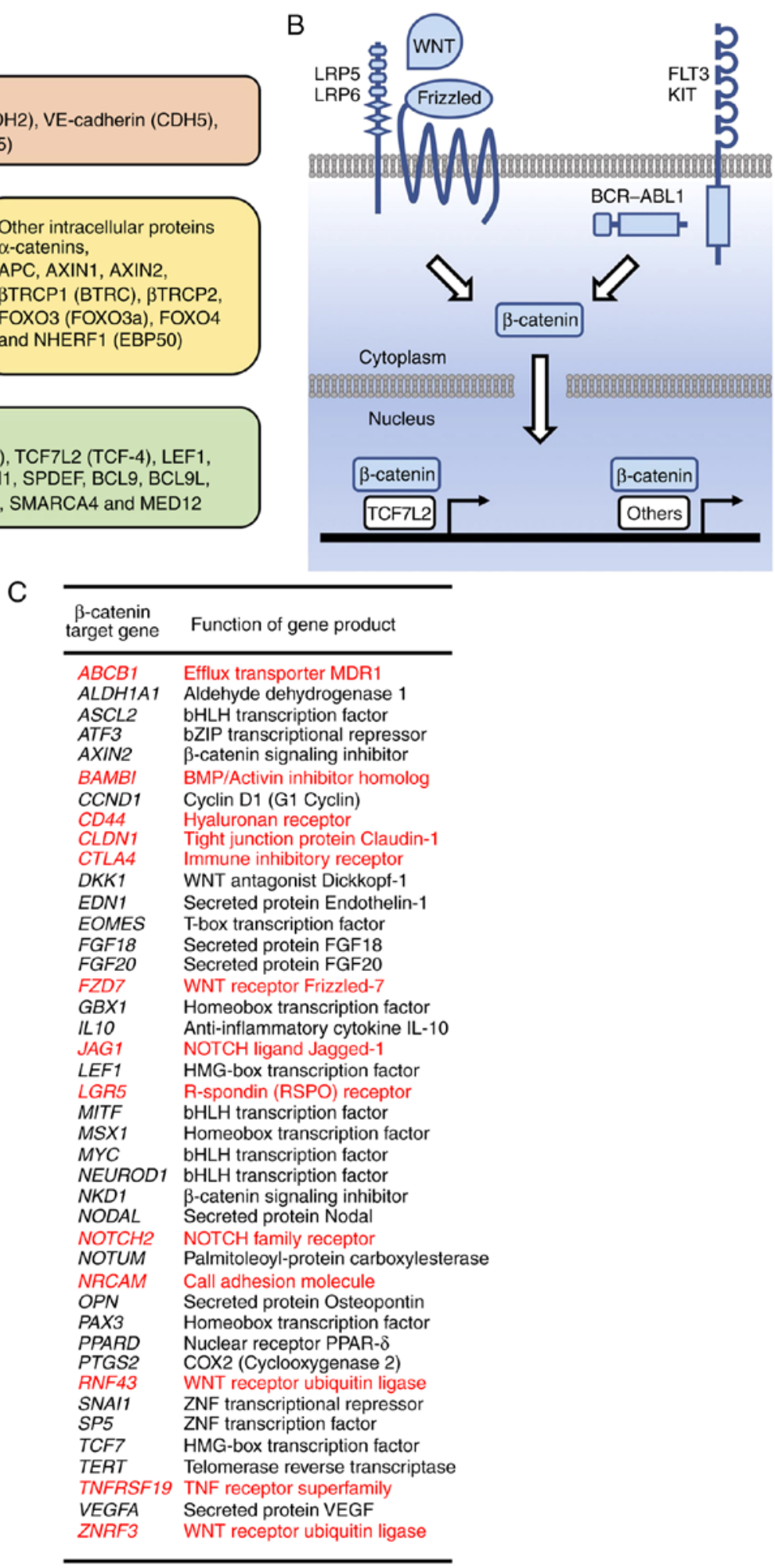

Figure 1. Overview of $\beta$-catenin functions at a glance. (A) Protein-protein interactions of $\beta$-catenin. $\beta$-catenin is a scaffold protein that interacts with adhesion molecules (E-cadherin, N-cadherin and VE-cadherin), transmembrane-type mucins (MUC1 and MUC16), signaling regulators (APC, AXIN1, AXIN2 and NHERF1) and epigenetic or transcriptional regulators (BCL9, BCL9L, CREBBP, EP300, FOXM1, LEF1, MED12, SMARCA4, TCF7, TCF7L1 and TCF7L2). $\beta$-catenin is involved in cell adhesion, intracellular signaling and transcription. The functions of $\beta$-catenin are regulated by its localization, protein-protein interactions and stability based on post-translational modifications. (B) $\beta$-catenin signaling into the nucleus. Canonical WNT signals prevent $\beta$-catenin phosphorylation at S33, S37, T41 and S45 to release $\beta$-catenin from ubiquitylation-mediated degradation, whereas oncogenic tyrosine kinases phosphorylate $\beta$-catenin at Y654 to release $\beta$-catenin from cadherin complexes. Stabilized $\beta$-catenin is translocated into the nucleus to activate the transcription of TCF/LEF-target genes and transcription dependent on other transcription factors in a cellular context-dependent manner based on epigenetic states and the availability of transcriptional regulators at the regulatory regions of target genes. (C) Transcriptional targets of $\beta$-catenin. ABCB1, ALDH1A1, ASCL2, ATF3, AXIN2, BAMBI, CCND1, CD44, CLDN1, CTLA4, DKK1, EDN1, EOMES, FGF18, FGF20, FZD7, GBX1, IL10, JAG1, LEF1, LGR5, MITF, MSX1, MYC, NEUROD1, NKD1, NODAL, NOTCH2, NOTUM, NRCAM, OPN, PAX3, PPARD, PTGS2, RNF43, SNAI1, SP5, TCF7, TERT, TNFRSF19, VEGFA and ZNRF3 are representative $\beta$-catenin target genes. $\beta$-catenin target genes encoding transmembrane proteins, including CD44v6, FZD7 and LGR5, are shown in red. Transmembrane proteins upregulated by the $\beta$-catenin signaling are rational targets of antibody-based drugs, including monoclonal antibodies, antibody-drug conjugates, bi-specific antibodies and chimeric antigen receptor-modified T cells. 

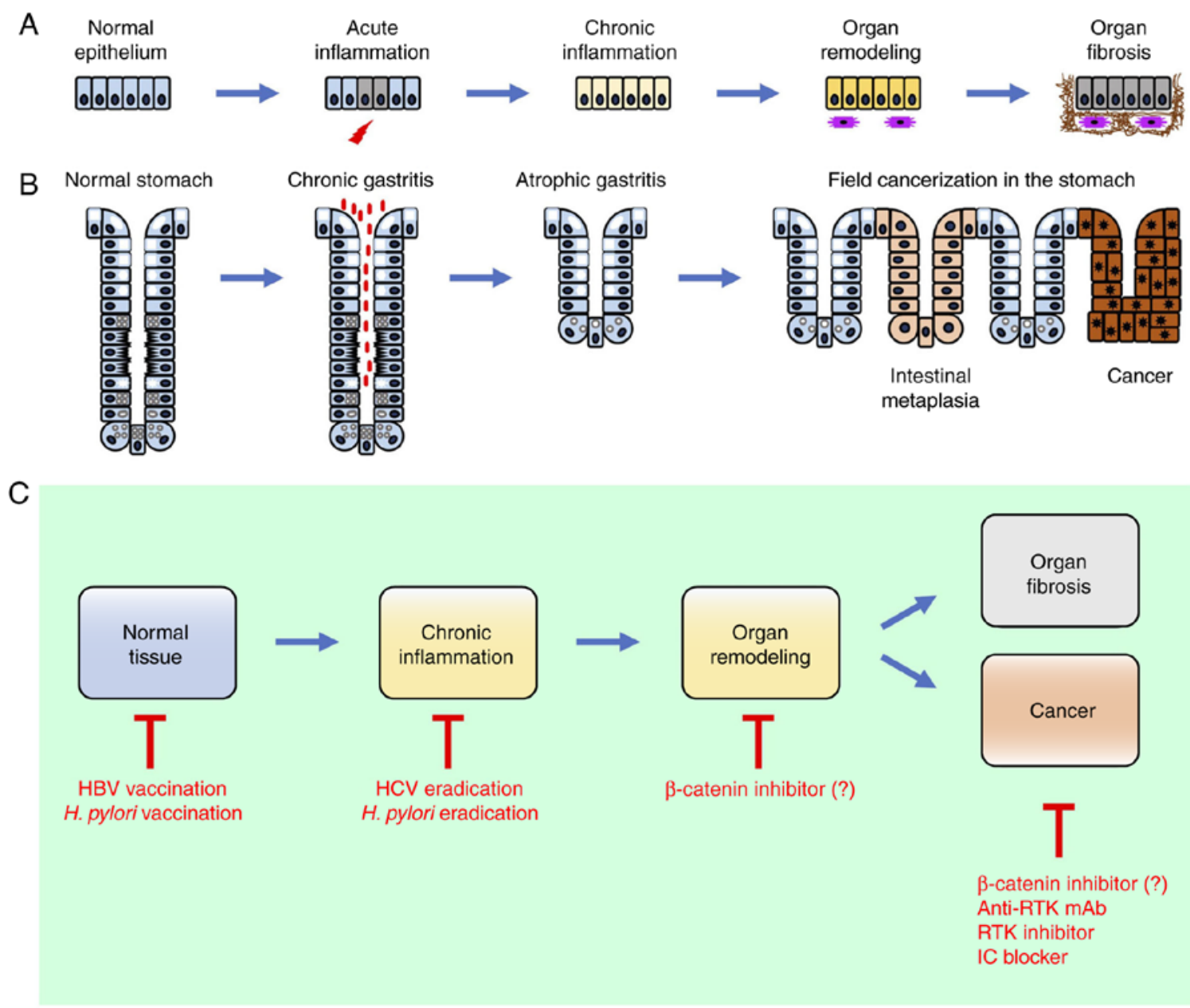

Figure 2. Precision medicine of chronic inflammation, organ fibrosis and cancer associated with aberrant $\beta$-catenin signaling activation. (A) Chronic persistent inflammation and fibrosis. The failure to resolve acute inflammation leads to chronic inflammation, organ remodeling and fibrosis with the subsequent deposition of extracellular matrix. $\beta$-catenin is involved in the activation of myofibroblast-like cells during organ remodeling and fibrosis. (B) Field cancerization in the stomach associated with $H$. pylori infection. Decades of persistent $H$. pylori infection lead to the sequential progression of chronic gastritis, atrophic gastritis, intestinal metaplasia and gastric cancer. During chronic active gastritis, $H$. pylori injects CagA into epithelial cells to activate MET and $\beta$-catenin signaling to promote epithelial proliferation. In a subset of human gastric cancer, the canonical WNT/ $\beta$-catenin signaling cascade is aberrantly activated due to gain-of-function mutations in the CTNNBl gene or loss-of-function mutations in the APC or $R N F 43$ gene. $\beta$-catenin is involved in $H$. pylori-related chronic active gastritis and gastric cancer. (C) Multi-layered prevention and treatment of $\beta$-catenin-related human diseases. Vaccines are available for the prevention of cancer-associated infections with HBV and H.pylori. The eradication of HCV and H.pylori is an optimal first-line prevention of field cancerization in the liver and stomach, respectively. Investigational $\beta$-catenin inhibitors are expected to be applicable for organ fibrosis prevention, second-line HCC prevention and treating $\beta$-catenin-driven cancer. The multi-layered prevention and treatment strategy of $\beta$-catenin-related human diseases is realistic for the practice of personalized medicine at present and necessary for the implementation of precision medicine in the future. H. pylori, Helicobacter pylori; HBV, hepatitis B virus; $\mathrm{HCV}$, hepatitis $\mathrm{C}$ virus; RTK, receptor tyrosine kinase; IC, immune checkpoint; mAb, monoclonal antibody.

colonizes the human stomach through interactions between bacterial BabA and HopQ adhesins to host ABO blood antigens and CEACAM, respectively $(49,50)$. H. pylori secretes urease for ammonia production from urea to survive in an microenvironment of high acidity, and they deliver CagA, VacA, $\gamma$-glutamyl transpeptidase and other virulence factors to the gastric microenvironment to elicit epithelial polarity dysregulation and mucosal damage, leading to pro-inflammatory cytokine secretion and immune tolerance $(51,52)$. Cytokine-mediated $\mathrm{T}$ helper cell (Th)1 and Th17 responses induce anti- $H$. pylori acquired immunity within $H$. pylori-colonized microenvironments, whereas the dendritic cell (DC)-mediated expansion of regulatory $\mathrm{T}$ (Treg) cells leads to immune evasion within the gastric microenvironment and cross-tolerance to allergens in extra-gastric microenvironments $(51,53)$.
In human organoid culture systems infected with H. pylori, CagA is injected into epithelial cells through the type IV secretion system and associates with the HGF receptor (MET) and hyaluronan receptor (CD44) to promote epithelial proliferation, in part through $\beta$-catenin signaling activation (54-56). By contrast, in a mouse model with artificial H. pylori infection, Rspo3 is upregulated to expand $\mathrm{Lgr}^{+}$ gastric stem/progenitor cells (57). As WNT2B (WNT-13) was originally cloned and characterized as a canonical WNT ligand derived from the human stomach $(58,59)$, RSPO3 can enhance canonical WNT/ $\beta$-catenin signaling activation through the release of Frizzled family WNT receptors from RNF43/ZNRN3-mediated repression $(1,60)$ and thus promote epithelial proliferation and gastric hyperplasia. The WNT/ $\beta$-catenin signaling cascade is aberrantly activated in human gastric cancer due to gain-of-function mutations in the 
CTNNB1 gene, as mentioned above, and to loss-of-function mutations in the $A P C$ and RNF43 genes (37). Together, these findings indicate that $\beta$-catenin serves key roles in $H$. pylori-related chronic active gastritis and gastric cancer.

Decades of persistent $H$. pylori infection lead to field cancerization in the stomach (Fig. 2B) through the sequential progression of chronic active gastritis, fundic gland atrophy, intestinal metaplasia and gastric cancer (61-63). Although $H$. pylori eradication in relatively older patients with irreversible gastric atrophy and intestinal metaplasia may not contribute to the prevention of gastric carcinogenesis due to preexisting genetic and epigenetic alterations in the premalignant lesions, $H$. pylori eradication in relatively younger patients with chronic active gastritis and/or reversible atrophy is optimal for the prevention of gastric carcinogenesis (Fig. 2C). A triple or quadruple regimen (proton-pump inhibitor, amoxicillin and clarithromycin with or without metronidazole) is prescribed for the eradication of $H$. pylori (64-67). To avoid the prevalence of drug-resistant $H$. pylori, the quadruple regimen is recommended for $H$. pylori eradication in Canada, Europe and the US.

By contrast, atezolizumab, avelumab, durvalumab, nivolumab and pembrolizumab are representative immune checkpoint inhibitors that are approved for the treatment of patients with certain types of cancer $(34,68)$. As H.pylori eradication eliminates $H$. pylori-related chronic inflammation and H. pylori-specific immune evasion, and reduces non-specific immune evasion caused by the DC-mediated Treg expansion and IL-10 elevation in the gastric microenvironment, $H$. pylori eradication may synergize with immune checkpoint inhibitors for the treatment of advanced gastric cancer with chronic active gastritis.

\section{Activation of $\beta$-catenin in liver fibrosis and hepatocellular carcinoma}

Chronic liver inflammation associated with hepatitis $\mathrm{C}$ virus (HCV) infection, hepatitis B virus (HBV) infection, alcohol abuse, non-alcoholic fatty liver disease and other etiologies leads to liver fibrosis due to the myofibroblast-like transition of hepatic stellate cells or other mesenchymal cells and subsequent accumulation of excessive ECM $(31,33)$. Liver cirrhosis is the most advanced stage of liver fibrosis, which is characterized by impaired liver functions and complications, including ascites, hepatic encephalopathy and upper gastrointestinal bleeding. Persistent liver inflammation leads to field cancerization in the liver through the sequential progression of chronic hepatitis, liver fibrosis and hepatocellular carcinoma (HCC) (69), similar to H. pylori-related field cancerization in the stomach (Fig. 2C).

The canonical WNT/ $\beta$-catenin signaling cascade is involved in the development and homeostasis of the liver $(70,71)$. Canonical WNT/ $\beta$-catenin signals promote the proliferation of $\mathrm{LGR}^{+}$hepatocyte progenitors in the peri-venous zone of hepatic lobules, whereas non-canonical WNT and other signals promote the proliferation of cholangiocyte progenitors in the peri-portal zone of hepatic lobules (71-73). Canonical Wnt-dependent Lgr5 ${ }^{+}$liver stem/progenitor cells in an organoid culture have successfully been applied in transplantation therapy for liver failure in a rat model (74).
$\mathrm{HCV}$ is a single-stranded RNA virus that infects hepatocytes to produce Core, NS3/4A, NS5A, NS5B and other viral proteins, and $\mathrm{HCV}$ upregulates the expression of $\beta$-catenin and MYC in hepatocytes (69). HBV is a partially double-stranded DNA virus that infects hepatocytes to produce HBx, pre-S, S and other viral proteins, and HBx upregulates the expression of EPCAM, $\beta$-catenin and MYC and activates NF- $\kappa \mathrm{B}$ signaling in hepatocytes (69). The RSPO-dependent activation of the $\mathrm{WNT} / \beta$-catenin signaling cascade is involved in the activation of hepatic stellate cells to promote liver fibrosis (75), whereas a $\beta$-catenin inhibitor (PRI-724) has been shown to prevent $\mathrm{HCV}$-related liver fibrosis in a mouse model (76). By contrast, the $\mathrm{WNT} / \beta$-catenin signaling cascade is aberrantly activated in human HCC due to gain-of-function mutations in the $C T N N B 1$ gene and loss-of-function mutations in the $A P C$ and $A X I N 1$ genes (35). Additionally, gain-of-function $\beta$-catenin mutations (S33Y or S45Y) and the overexpression of Met have been shown to synergistically promote liver tumorigenesis in a mouse model (77), whereas an oncolytic adenovirus Ad.wnt-E1A( $\triangle 24 \mathrm{bp})$-TSLC1 has been shown to effectively target liver cancer cells with aberrant $\beta$-catenin-TCF/LEF signaling activation and repress in vivo tumorigenesis and metastasis (78). $\beta$-catenin plays key roles in multiple processes of chronic inflammation-related liver pathophysiology, including hepatocyte proliferation, stellate-cell activation, liver fibrosis and liver tumorigenesis.

The eradication of $\mathrm{HCV}$ is predicted to be an optimal approach to prevent HCC; as such, the eradication of $H$.pylori may be used to prevent gastric cancer. Direct-acting antivirals, including HCV NS3/4A protease inhibitors (glecaprevir and paritaprevir), HCV NS5A inhibitors (ledipasvir, ombitasvir, pibrentasvir and velpatasvir) and HCV NS5B RNA polymerase inhibitors (dasabuvir and sofosbuvir), have been developed for the eradication of HCV. For example, glecaprevir/pibrentasvir and velpatasvir/sofosbuvir are combination drugs that are approved for the treatment of HCV genotypes 1, 2, 3, 4, 5 and $6(79,80)$. Studies in Italy and Spain revealed that the occurrence and recurrence of $\mathrm{HCC}$ were not prevented by $\mathrm{HCV}$ eradication $(81,82)$, whereas a study in Japan revealed that the occurrence of HCC was successfully prevented by HCV eradication (83). As complications of non-viral etiologies of chronic liver inflammation, ethnic or genetic backgrounds, stages of liver fibrosis, and genomic or epigenetic alterations in premalignant lesions may affect the outcomes of $\mathrm{HCV}$ eradication, further investigations in larger cohorts are necessary to address the controversy regarding the rate of $\mathrm{HCC}$ development following $\mathrm{HCV}$ eradication.

\section{Activation of $\beta$-catenin in pulmonary fibrosis and lung cancer}

Fibrosis is a common pathology of chronic inflammation in the liver and other organs, including the lungs, heart and kidneys $(31,32)$. Irreversible pulmonary fibrosis, cardiac fibrosis or renal fibrosis leads to organ destruction and subsequent decompensation, which is the final serious condition in patients with non-cancerous diseases. For example, cardiac fibrosis is caused by the transformation of cardiac fibroblasts into myofibroblasts and leads to myocardial stiffness and ventricular dysfunction (32), whereas pulmonary fibrosis 
is caused by chronic inflammation associated with cancer therapy, cigarette smoking, connective tissue diseases, environmental pollution, infection, pulmonary hypertension and idiopathic pulmonary fibrosis $(84,85)$.

Airway damage-induced canonical WNT/ $\beta$-catenin signaling activation in alveolar epithelial type II cells promotes the activation and remodeling of interstitial fibroblasts; transient remodeling leads to resolution, whereas persistent remodeling leads to pulmonary fibrosis $(31,85)$. Canonical WNT/ $\beta$-catenin signaling activation in pulmonary endothelial cells activates perivascular fibroblasts to undergo a myofibroblast-like transition, which also leads to ECM accumulation and increased tissue stiffness, further promoting pulmonary fibrosis $(86,87)$. Pulmonary injuries also induce the chemokine-dependent recruitment of monocytes and their subsequent transition into monocyte-derived alveolar macrophages that express higher levels of pro-inflammatory and pro-fibrotic genes than tissue-resident alveolar macrophages (88). However, $\beta$-catenin inhibitors, including ICG-001 and XAV939, ameliorate chronic lung injury and prevent the progression to severe pulmonary fibrosis $(89,90)$. The canonical WNT/ $\beta$-catenin signaling cascade is involved in the pathogenesis of pulmonary fibrosis.

Genetic alterations in the canonical WNT/ $\beta$-catenin signaling regulators are relatively rare in human lung cancer (91). However, lung CSCs differentiate into WNT-producing supporting cells to maintain the stemness of CSCs and promote the expansion of bulk tumor cells (92). The upregulation of RSPO2 or RSPO3 leads to canonical $\mathrm{WNT} / \beta$-catenin signaling activation in patient-derived xenograft (PDX) models of human lung cancer (93), and nuclear $\beta$-catenin staining is associated with poor prognosis in patients with lung cancer $(94,95)$. Despite relatively infrequent genetic alterations, the canonical $\mathrm{WNT} / \beta$-catenin signaling cascade is involved in multi-step tumorigenesis in the human lungs through WNT- and RSPO-dependent paracrine signaling.

Receptor tyrosine kinases (RTKs), including ALK, DDR2, EGFR, FGFR1, FGFR2, HER2, MET, NTRK1, RET and ROS1, are aberrantly activated in human lung cancer due to gene amplification, gene fusions or point mutations (96-99). Although ALK inhibitors (alectinib and ceritinib), an ALK/ROS1 inhibitor (crizotinib) and EGFR inhibitors (afatinib, erlotinib, gefitinib and osimertinib) are approved for the treatment of patients with lung cancer, drug resistance and recurrence are difficult to avoid due to acquired mutations in the targeted RTKs, the by-passed activation of other RTKs and $\beta$-catenin signaling activation (34). Therapy-related chronic inflammation, in addition to cancer-cell plasticity and intra-tumor heterogeneity, lead to resistance to RTK-targeted therapeutics, in part through canonical WNT signaling activation.

\section{Therapeutics targeting $\beta$-catenin for preventing organ fibrosis or treating cancer}

$\beta$-catenin is involved in chronic inflammation, organ fibrosis and carcinogenesis; however, $\beta$-catenin lacking intrinsic enzymatic activity is a difficult target for drug development. Antibody-based or decoy-receptor drugs targeting ligands or receptors involved in canonical WNT signaling and small-molecule compounds targeting porcupine (PORCN), tankyrase (TNKS) and $\beta$-catenin PPIs have been developed as $\beta$-catenin inhibitors for preclinical studies and/or clinical trials (34). In addition to these investigational drugs, small-moleculecompounds targeting epigenetic/transcriptional regulators involved in $\beta$-catenin-dependent transcription and antibody- or peptide-based drugs binding to $\beta$-catenin-target gene products have also been suggested as $\beta$-catenin inhibitors. $\beta$-catenin-targeted therapeutics are functionally classified as follows: i) $\beta$-catenin inhibitors targeting upstream regulators, ii) $\beta$-catenin inhibitors targeting PPIs, iii) $\beta$-catenin inhibitors targeting epigenetic regulators, iv) $\beta$-catenin inhibitors targeting mediator complexes, and v) $\beta$-catenin inhibitors targeting transcriptional outputs (Fig. 3). Follows is a discussion of the pros and cons of each $\beta$-catenin inhibitor class.

$\beta$-catenin inhibitors targeting upstream regulators. Anti-FZD1/2/5/7/8 monoclonal antibody (mAb) (vantictumab) (100), anti-FZD5 mAb (IgG-2919) (101), anti-RSPO3 m Ab (rosmantuzumab) (102), FZD8-Fc (ipafricept) (103), PORCN inhibitors (ETC-159, GNF6231, WNT-C59 and WNT974) (104-107) and TNKS inhibitors (AZ1366, G007-LK, NVP-TNKS656 and XAV939) (108-111) are therapeutics targeting upstream regulators of $\beta$-catenin (Fig. 3). The on-target effects on $\beta$-catenin-independent WNT signaling cascades are potential risks for anti-FZD mAbs, FZD8-Fc and PORCN inhibitors, whereas the on-target effects on WNT-independent signaling cascades are potential risks for TNKS inhibitors (34). ETC-159, ipafricept, rosmantuzumab, vantictumab and WNT974 are in clinical trials for the treatment of cancer patients.

$\beta$-catenin inhibitors targeting PPIs. CGP049090 (112), CWP232228 (113), E7386 (114), ICG-001 (89), LF3 (115) and PRI-724 (116) are representative therapeutics targeting $\beta$-catenin PPIs (Fig. 3). CGP049090, CWP232228 and LF3 inhibit the PPI between $\beta$-catenin and TCF, whereas E7386, ICG-001 and PRI-724 inhibit the PPI between $\beta$-catenin and CREBBP. Although E7386, ICG-001 and PRI-724 are claimed to repress CREBBP-dependent stemness-related transcription and reciprocally enhance EP300-dependent differentiation-related transcription, this hypothesis remains to be generalized for various types of primary tumors with complex genetic alterations. In addition, the specificities of therapeutics targeting $\beta$-catenin PPI remain to be elucidated. E7386 is in a clinical trial for cancer patients, whereas PRI-724 is in clinical trials for patients with cancer or liver fibrosis.

$\beta$-catenin inhibitors targeting epigenetic regulators. Epigenetic components that permit access of the $\beta$-catenin complex to the promoter and enhancer regions of its target genes are downstream regulators of $\beta$-catenin-dependent transcription (Fig. 3). JMJD2A (KDM4A), JMJD2B (KDM4B) and JMJD2C (KDM4C) are Jumonji domain-containing enzymes that demethylate histone $\mathrm{H} 3$ at $\mathrm{K} 9$ and $\mathrm{K} 36$ (H3K9 and H3K36) $(117,118)$. JMJD2C associated with $\beta$-catenin and chromatin is required for the expression of CCND1 and cell growth in colorectal cancer cells (119). Mouse Jmjd2a and $\mathrm{Jmjd} 2 \mathrm{c}$ are required for the self-renewal of embryonic stem 

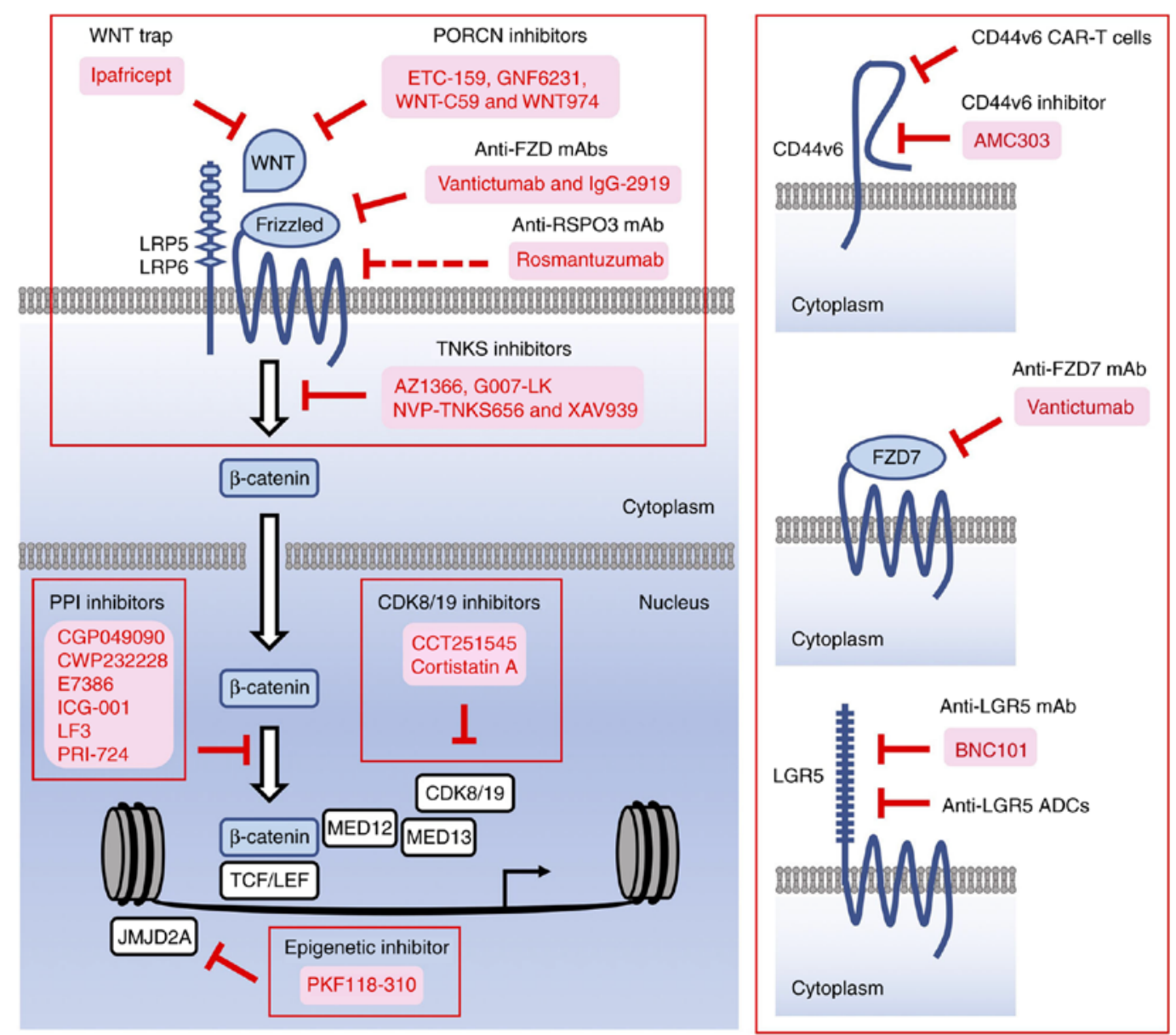

Figure 3. Investigational $\beta$-catenin inhibitors and mechanisms of action. $\beta$-catenin-targeted therapeutics are functionally classified as i) $\beta$-catenin inhibitors targeting upstream regulators (AZ1366, ETC-159, G007-LK, GNF6231, ipafricept, NVP-TNKS656, rosmantuzumab, vantictumab, WNT-C59, WNT974 and XAV939), ii) $\beta$-catenin inhibitors targeting PPIs (CGP049090, CWP232228, E7386, ICG-001, LF3 and PRI-724), iii) $\beta$-catenin inhibitors targeting epigenetic regulators (PKF118-310), iv) $\beta$-catenin inhibitors targeting mediator complexes (CCT251545 and cortistatin A), and v) $\beta$-catenin inhibitors targeting transcriptional outputs [CD44v6 chimeric antigen receptor-modified T cells, CD44v6 inhibitor AMC303, anti-FZD7 mAb cross-reacting with FZD1, FZD2, FZD5 and FZD8 (vantictumab), anti-LGR5 mAb BNC101 and anti-LGR5 ADCs]. AMC303, BNC101, ETC-159, ipafricept, PRI-724, rosmantuzumab, vantictumab and WNT974 are in clinical trials, whereas other investigational $\beta$-catenin inhibitors are in preclinical stages. PPIs, protein-protein interactions; ADCs, antibody-drug conjugates; PORCN, porcupine; TNKS, tankyrase; mAb, monoclonal antibody.

cells (ESCs) (120), and Jmjd2c associated with a mediator complex is required for the lineage-specific gene expression and multi-lineage differentiation of ESCs (121). PKF118-310 was initially identified as a compound that inhibits $\beta$-catenin-dependent transcription via inhibition of the interaction between $\beta$-catenin and TCF7L2, and PKF118-310 has been re-discovered as a JMJD2A inhibitor $(8,122,123)$. PKF118-310 has been shown to exert antitumor effects on colorectal cancer and prostate cancer in vitro and breast cancer and HCC in vivo $(122,124,125)$. PKF118-310 also exerts antifibrotic effects in mouse models of dermal fibrosis (126). Other epigenetic regulators, including EZH2 $(127,128)$, KDM1A (LSD1) (129) and PRMT5 (130), are also involved in canonical WNT/ $\beta$-catenin signaling activation in certain contexts. As epigenetic regulators are desirable targets in the field of clinical oncology (127,131-134), EZH2 inhibitors, including GSK2816126 and tazemetostat/EPZ-6438), KDM1A inhibitors, including GSK2879552 and pargyline, and PRMT5 inhibitors, including GSK3235025/EPZ015666 and PJ-68, have been developed; however, the mechanisms of action of these investigational drugs on $\beta$-catenin-dependent transcription require further clarification to identify biomarkers for patient selection. PKF118-310 is a promising compound to be optimized for the treatment of patients with $\beta$-catenin-dependent fibrosis and cancer.

$\beta$-catenin inhibitors targeting mediator complexes. Mediator complexes that assemble transcription factors, cofactors and other regulators of RNA polymerase II-mediated mRNA synthesis are involved in the $\beta$-catenin-dependent transcription of oncogenic targets, including CCNDI and MYC (135-137) (Fig. 3). $\beta$-catenin binds to MED12, which associates with MED13, cyclin C (CCNC) and CDK8/19 to form the kinase module of the mediator complex. As CDK8 and CDK19 are key components of the mediator complex, CCT251545 $(138,139)$ and cortistatin A $(140,141)$ have been characterized as CDK8/19 inhibitors that suppress $\beta$-catenin-dependent transcription and the in vivo tumorigenesis of colorectal cancer, breast cancer and acute myeloid leukemia. CDK8/19 phosphorylates mediator complex components (CCNC, MED12, MED13, MED14 and MED26), epigenetic regulators (BCL9, BPTF, BRD9, KDM3A, MLL2, SETD1A and SIRT1) and 
transcription factors or cofactors (ATF7, FOXC1, KLF12 and STAT1) (141). Additionally, mediator complexes are involved in $\beta$-catenin-dependent transcription and transcription dependent on other transcription factors $(136,137)$. Due to the unknown on-target effects associated with the various functions of CDK9/18 and mediator complexes, the application of CDK9/18 inhibitors for the treatment of patients with WNT-driven cancer has been suspended at the preclinical stage.

$\beta$-catenin inhibitors targeting transcriptional outputs. ABCB1, BAMBI, CD44, CLDN1, CTLA4, FZD7, JAG1, LGR5, NOTCH2, NRCAM, RNF43, TNFRSF19 and ZNRF3 are representative $\beta$-catenin target genes that encode transmembrane proteins (Fig. 1C). For example, the CD44v6 isoform that functions as a positive regulator of canonical WNT, CXCL12 (SDF1), FGF2, HGF, OPN and VEGF signaling in CSCs is involved in malignant phenotypical characteristics, including the EMT, tumor cell invasion and metastasis, therapeutic resistance and recurrence (142-145). FZD7 is a seven-transmembrane receptor, which transduces canonical and non-canonical WNT signaling in a context-dependent manner, whereas LGR5 is a seven-transmembrane receptor, which transduces RSPO signaling and potentiates WNT signaling through FZD receptors $(8,24,34,146-149)$. Other transmembrane-type $\beta$-catenin signaling outputs are also involved in various pathophysiological aspects of human diseases.

As transmembrane proteins expressed on tumor cells are appropriate targets for the development of peptide-based drugs(142),mAbs, antibody-drug conjugates(ADCs),bi-specific antibodies (bsAbs) and chimeric antigen receptor-modified $\mathrm{T}$ cells (150-155), drugs targeting CD44v6, FZD7 and LGR5 are under development as functional $\beta$-catenin inhibitors. CD44v6 CAR-T cells (156) and anti-LGR5 ADCs $(157,158)$ and are in preclinical stages, whereas the phase I clinical trial of anti-CD44v6 ADC (bivatuzumab mertansine) for patients with head and neck squamous cell carcinoma was terminated due to severe on-target skin toxicities (159). A peptide-based CD44v6 inhibitor (AMC303) (160) is in a phase I clinical trial for the treatment of patients with advanced solid tumors (ClinicalTrials.gov Identifier: NCT03009214); anti-FZD7 mAb (vantictumab), which cross-reacts with FZD1,FZD2, FZD5 and FZD8 (100), is in phase I clinical trials for cancer patients, as mentioned above (ClinicalTrials.gov Identifier: NCT01957007 and NCT01973309); anti-LGR5 mAb (BNC101) (161) is also in a phase I clinical trial for cancer patients (ClinicalTrials.gov Identifier: NCT02726334). Antibody- or peptide-based drugs are promising options for the treatment of $\beta$-catenin-driven human diseases; however, further evaluation of the benefits, costs and on-target toxicities are necessary prior to clinical application.

\section{Multi-layered prevention and treatment of $\beta$-catenin- related diseases}

Clinical medicine, particularly clinical oncology, is moving toward genomics-based personalized medicine due to the development of nucleotide sequence technologies. Such personalized medicine is expected to further evolve into omics- and clinical record-based precision medicine with relatively inexpensive costs due to increasing medical expenses in aging societies (162). Genomics-based testing platforms, including MSK-IMPACT (43), FoundationOne (163) and Oncomine Comprehensive Panel (164), and organoid- or PDX-based drug screening (165-167) are useful tools for the prescription of targeted therapeutics; however, there remain unmet medical needs for patients with refractory cancer driven by gain-of-function mutations in non-enzymatic oncogenes, including $C T N N B 1$ and $K R A S$, or loss-of-function mutations in tumor-suppressor genes, including $A P C$ and TP53.

$\beta$-catenin signaling is involved in myofibroblast activation and subsequent organ fibrosis (Fig. 2A), whereas the activation of $\beta$-catenin and NF- $\kappa \mathrm{B}$ signaling is involved in field cancerization in the liver associated with $\mathrm{HBV}, \mathrm{HCV}$ and other etiologies, and field cancerization in the stomach associated with H.pylori infection (Fig. 2B). Vaccines against HBV and H. pylori are available for the prevention of cancer-associated infections $(168,169)$. The eradication of $\mathrm{HCV}$ and $H$. pylori are optimal choices for the first-line prevention of HCC and gastric cancer, respectively (Fig. 2C); however, pathogen eradication is not always successful and may occur too late to reverse the process of field cancerization. $\beta$-catenin inhibitors are expected to be applicable for organ fibrosis prevention, second-line HCC prevention and treating $\beta$-catenin-driven cancer (Fig. 2C). Although $\beta$-catenin without intrinsic enzymatic activity is difficult to target in drug development, several classes of investigational $\beta$-catenin inhibitors (Fig. 3) are in preclinical stages or clinical trials for treating patients with $\beta$-catenin-related diseases. The multi-layered prevention and treatment strategy of $\beta$-catenin-related human diseases is realistic at present and necessary for the implementation of precision medicine in the future.

\section{Acknowledgements}

Not applicable.

\section{Funding}

This study was financially supported in part by a grant-in-aid for the Knowledgebase Project from M. Katoh's Fund.

\section{Availability of data and materials}

Not applicable.

\section{Authors' contributions}

MK analyzed the literatures, designed and wrote the study, and produced the figures.

\section{Ethics approval and consent to participate}

Not applicable.

\section{Consent for publication}

Not applicable. 


\section{Competing interests}

The author declares that he has no competing interests.

\section{References}

1. Katoh M and Katoh M: Molecular genetics and targeted therapy of WNT-related human diseases (Review). Int J Mol Med 40: 587-606, 2017.

2. Takeichi M: Dynamic contacts: Rearranging adherens junctions to drive epithelial remodelling. Nat Rev Mol Cell Biol 15: 397-410, 2014.

3. McCrea PD and Gottardi CJ: Beyond $\beta$-catenin: Prospects for a larger catenin network in the nucleus. Nat Rev Mol Cell Biol 17: 55-64, 2016.

4. Kufe DW: MUC1-C oncoprotein as a target in breast cancer: Activation of signaling pathways and therapeutic approaches. Oncogene 32: 1073-1081,2013.

5. Liu Q, Cheng Z, Luo L, Yang Y, Zhang Z, Ma H, Chen T, Huang X, Lin SY, Jin M, et al: C-terminus of MUC16 activates Wnt signaling pathway through its interaction with $\beta$-catenin to promote tumorigenesis and metastasis. Oncotarget 7 : 36800-36813, 2016

6. Klaus A and Birchmeier W: Wnt signalling and its impact on development and cancer. Nat Rev Cancer 8: 387-398, 2008.

7. Vaquero J, Nguyen Ho-Bouldoires TH, Clapéron A and Fouassier L: Role of the PDZ-scaffold protein NHERF1/EBP50 in cancer biology: From signaling regulation to clinical relevance. Oncogene 36: 3067-3079, 2017

8. Katoh M and Katoh M: WNT signaling pathway and stem cell signaling network. Clin Cancer Res 13: 4042-4045, 2007.

9. Valenta T, Hausmann $\mathrm{G}$ and Basler K: The many faces and functions of $\beta$-catenin. EMBO J 31: 2714-2736, 2012.

10. Lo YH, Noah TK, Chen MS, Zou W, Borras E, Vilar E and Shroyer NF: SPDEF induces quiescence of colorectal cancer cells by changing the transcriptional targets of $\beta$-catenin. Gastroenterology 153: 205-218.e8, 2017.

11. Frescas D and Pagano M: Deregulated proteolysis by the F-box proteins SKP2 and $\beta$-TrCP: Tipping the scales of cancer. Nat Rev Cancer 8: 438-449, 2008.

12. Novellasdemunt L, Foglizzo V, Cuadrado L, Antas P, Kucharska A, Encheva V, Snijders AP and Li VSW: USP7 is a tumor-specific WNT activator for APC-mutated colorectal cancer by mediating $\beta$-catenin deubiquitination. Cell Rep 21 612-627, 2017.

13. Hoffmeyer K, Junghans D, Kanzler B and Kemler R: Trimethylation and acetylation of $\beta$-catenin at Lysine 49 represent key elements in ESC pluripotency. Cell Rep 18: 2815-2824, 2017.

14. Alok A, Lei Z, Jagannathan NS, Kaur S, Harmston N, Rozen SG, Tucker-Kellogg L and Virshup DM: Wnt proteins synergize to activate $\beta$-catenin signaling. J Cell Sci 130: 1532-1544, 2017.

15. Herbst A, Jurinovic V, Krebs S, Thieme SE, Blum H, Göke B and Kolligs FT: Comprehensive analysis of $\beta$-catenin target genes in colorectal carcinoma cell lines with deregulated Wnt/ $\beta$-catenin signaling. BMC Genomics 15: 74, 2014.

16. Watanabe K, Biesinger J, Salmans ML, Roberts BS, Arthur WT, Cleary M, Andersen B, Xie X and Dai X: Integrative ChIP-seq/microarray analysis identifies a CTNNB1 target signature enriched in intestinal stem cells and colon cancer. PLoS One 9: e92317, 2014

17. Funa NS, Schachter KA, Lerdrup M,Ekberg J,Hess K, Dietrich N, Honoré $\mathrm{C}$, Hansen $\mathrm{K}$ and Semb $\mathrm{H}$ : $\beta$-Catenin regulates primitive streak induction through collaborative interactions with SMAD2/SMAD3 and OCT4. Cell Stem Cell 16: 639-652, 2015.

18. Condello S, Morgan CA, Nagdas S, Cao L, Turek J, Hurley TD and Matei D: $\beta$-Catenin-regulated ALDH1A1 is a target in ovarian cancer spheroids. Oncogene 34: 2297-2308, 2015

19. Spranger S, Bao R and Gajewski TF: Melanoma-intrinsic $\beta$-catenin signalling prevents anti-tumour immunity. Nature 523 231-235, 2015

20. Yun EJ, Zhou J, Lin CJ, Hernandez E, Fazli L, Gleave M and Hsieh JT: Targeting cancer stem cells in castration-resistant prostate cancer. Clin Cancer Res 22: 670-679, 2016.

21. Miwa N, Furuse M, Tsukita S, Niikawa N, Nakamura $Y$ and Furukawa Y: Involvement of Claudin-1 in the $\beta$-catenin/Tcf signaling pathway and its frequent upregulation in human colorectal cancers. Oncol Res 12: 469-476, 2001.
22. Shah KV, Chien AJ, Yee C and Moon RT: CTLA-4 is a direct target of $\mathrm{Wnt} / \beta$-catenin signaling and is expressed in human melanoma tumors. J Invest Dermatol 128: 2870-2879, 2008.

23. Yan KS, Janda CY, Chang J, Zheng GXY, Larkin KA, Luca VC, Chia LA, Mah AT, Han A, Terry JM, et al: Non-equivalence of Wnt and R-spondin ligands during $\mathrm{Lgr}^{+}$intestinal stem-cell self-renewal. Nature 545: 238-242, 2017.

24. Kaur A, Webster MR and Weeraratna AT: In the Wnt-er of life: Wnt signalling in melanoma and ageing. Br J Cancer 115: 1273-1279, 2016

25. Ravindranath A, Yuen HF, Chan KK, Grills C, Fennell DA, Lappin TR and El-Tanani M: Wnt- $\beta$-catenin-Tef- 4 signalling-modulated invasiveness is dependent on osteopontin expression in breast cancer. Br J Cancer 105: 542-551, 2011

26. Gnemmi V, Bouillez A, Gaudelot K, Hémon B, Ringot B, Pottier N, Glowacki F, Villers A, Vindrieux D, Cauffiez C, et al: MUC1 drives epithelial-mesenchymal transition in renal carcinoma through Wnt/ $\beta$-catenin pathway and interaction with SNAIL promoter. Cancer Lett 346: 225-236, 2014.

27. Low KC and Tergaonkar V: Telomerase: Central regulator of all of the hallmarks of cancer. Trends Biochem Sci 38: 426-434, 2013.

28. Schön S, Flierman I, Ofner A, Stahringer A, Holdt LM, Kolligs FT and Herbst A: $\beta$-catenin regulates NF- $\kappa$ B activity via TNFRSF19 in colorectal cancer cells. Int J Cancer 135: 1800-1811, 2014.

29. De Jaime-Soguero A, Aulicino F, Ertaylan G, Griego A, Cerrato A, Tallam A, Del Sol A, Cosma MP and Lluis F: Wnt/Tcf1 pathway restricts embryonic stem cell cycle through activation of the Ink4/Arf locus. PLoS Genet 13: e1006682, 2017.

30. Ring A, Kim YM and Kahn M: Wnt/catenin signaling in adult stem cell physiology and disease. Stem Cell Rev Rep 10: 512-525, 2014.

31. Bataller R and Brenner DA: Liver fibrosis. J Clin Invest 115: 209-218, 2005.

32. Wynn TA and Ramalingam TR: Mechanisms of fibrosis: Therapeutic translation for fibrotic disease. Nat Med 18: 1028-1040, 2012

33. Monga SP: $\beta$-catenin signaling and roles in liver homeostasis, injury, and tumorigenesis. Gastroenterology 148: 1294-1310, 2015.

34. Katoh M: Canonical and non-canonical WNT signaling in cancer stem cells and their niches: Cellular heterogeneity, omics reprogramming, targeted therapy and tumor plasticity. Int J Oncol 51: $1357-1369,2017$.

35. Guichard C, Amaddeo G, Imbeaud S, Ladeiro Y, Pelletier L, Maad IB, Calderaro J, Bioulac-Sage P, Letexier M, Degos F, et al: Integrated analysis of somatic mutations and focal copy-number changes identifies key genes and pathways in hepatocellular carcinoma. Nat Genet 44: 694-698, 2012.

36. Kandoth C, McLellan MD, Vandin F, Ye K, Niu B, Lu C, Xie M, Zhang Q, McMichael JF, Wyczalkowski MA, et al: Mutational landscape and significance across 12 major cancer types. Nature 502: 333-339, 2013.

37. Cancer Genome Atlas Research Network: Comprehensive molecular characterization of gastric adenocarcinoma. Nature 513: 202-209, 2014.

38. Robinson D, Van Allen EM, Wu YM, Schultz N, Lonigro RJ, Mosquera JM, Montgomery B, Taplin ME, Pritchard CC, Attard G, et al: Integrative clinical genomics of advanced prostate cancer. Cell 161: 1215-1228, 2015.

39. Teo AE, Garg S, Shaikh LH, Zhou J, Karet Frank1 FE, Gurnell M, Happerfield L, Marker A, Bienz M, Azizan EA and Brown MJ: Pregnancy, primary aldosteronism, and adrenal CTNNB1 mutations. N Engl J Med 373: 1429-1436, 2015.

40. Bailey P, Chang DK, Nones K, Johns AL, Patch AM, Gingras MC, Miller DK, Christ AN, Bruxner TJ, Quinn MC, et al: Genomic analyses identify molecular subtypes of pancreatic cancer. Nature 531: 47-52, 2016

41. Cancer Genome Atlas Network: Comprehensive genomic characterization of head and neck squamous cell carcinomas. Nature 517: 576-582, 2015.

42. Cancer Genome Atlas Research Network; Analysis Working Group: Asan University; BC Cancer Agency; Brigham and Women's Hospital; Broad Institute; Brown University; Case Western Reserve University; Dana-Farber Cancer Institute; Duke University, et al: Integrated genomic characterization of oesophageal carcinoma. Nature 541: 169-175, 2017. 
43. Zehir A, Benayed R, Shah RH, Syed A, Middha S, Kim HR Srinivasan P, Gao J, Chakravarty D, Devlin SM, et al: Mutational landscape of metastatic cancer revealed from prospective clinical sequencing of 10,000 patients. Nat Med 23: 703-713, 2017.

44. Kaur A, Webster MR, Marchbank K, Behera R, Ndoye A, Kugel CH III, Dang VM, Appleton J, O'Connell MP, Cheng P, et al: sFRP2 in the aged microenvironment drives melanoma metastasis and therapy resistance. Nature 532: 250-254, 2016.

45. Webster MR, Kugel CH III and Weeraratna AT: The Wnts of change: How Wnts regulate phenotype switching in melanoma. Biochim Biophys Acta 1856: 244-251, 2015.

46. Bui T, Schade B, Cardiff RD, Aina OH, Sanguin-Gendreau V and Muller WJ: $\beta$-Catenin haploinsufficiency promotes mammary tumorigenesis in an ErbB2-positive basal breast cancer model. Proc Natl Acad Sci USA 114: E707-E716, 2017.

47. Beltran H, Prandi D, Mosquera JM, Benelli M, Puca L, Cyrta J, Marotz C, Giannopoulou E, Chakravarthi BV, Varambally S, et al: Divergent clonal evolution of castration-resistant neuroendocrine prostate cancer. Nat Med 22: 298-305, 2016.

48. Rheinbay E, Parasuraman P, Grimsby J, Tiao G, Engreitz JM, Kim J, Lawrence MS, Taylor-Weiner A, Rodriguez-Cuevas S, Rosenberg M, et al: Recurrent and functional regulatory mutations in breast cancer. Nature 547: 55-60, 2017

49. Bugaytsova JA, Björnham O, Chernov YA, Gideonsson P Henriksson S, Mendez M, Sjöström R, Mahdavi J, Shevtsova A, Ilver D, et al: Helicobacter pylori adapts to chronic infection and gastric disease via pH-responsive BabA-mediated adherence. Cell Host Microbe 21: 376-389, 2017.

50. Javaheri A, Kruse T, Moonens K, Mejías-Luque R, Debraekeleer A, Asche CI, Tegtmeyer N, Kalali B, Bach NC, Sieber SA, et al: Helicobacter pylori adhesin HopQ engages in a virulence-enhancing interaction with human CEACAMs. Nat Microbiol 2: 16189, 2016.

51. Salama NR, Hartung ML and Müller A: Life in the human stomach: Persistence strategies of the bacterial pathogen Helicobacter pylori. Nat Rev Microbiol 11: 385-399, 2013.

52. Yamaoka Y and Graham DY: Helicobacter pylori virulence and cancer pathogenesis. Future Oncol 10: 1487-1500, 2014.

53. Käbisch R, Mejías-Luque R, Gerhard M and Prinz C: Involvement of Toll-like receptors on Helicobacter pylori-induced immunity. PLoS One 9: e104804, 2014.

54. McCracken KW, Catá EM, Crawford CM, Sinagoga KL, Schumacher M, Rockich BE, Tsai YH, Mayhew CN, Spence JR Zavros Y and Wells JM: Modelling human development and disease in pluripotent stem cell-derived gastric organoids. Nature 516: 400-404, 2014.

55. Bertaux-Skeirik N, Feng R, Schumacher MA, Li J, Mahe MM, Engevik AC, Javier JE, Peek RM Jr, Ottemann K, Orian-Rousseau V, et al: CD44 plays a functional role in Helicobacter pylori-induced epithelial cell proliferation. PLoS Pathog 112: e1004663, 2015.

56. Song X, Xin N, Wang W and Zhao C: Wnt//-catenin, an oncogenic pathway targeted by $\mathrm{H}$. pylori in gastric carcinogenesis. Oncotarget 6: 35579-35588, 2015.

57. Sigal M, Logan CY, Kapalczynska M, Mollenkopf HJ, Berger H, Wiedenmann B, Nusse R, Amieva MR and Meyer TF: Stromal R-spondin orchestrates gastric epithelial stem cells and gland homeostasis. Nature 548: 451-455, 2017.

58. Katoh M, Hirai M, Sugimura T and Terada M: Cloning, expression and chromosomal localization of Wnt-13, a novel member of the Wnt gene family. Oncogene 13: 873-876, 1996.

59. Katoh M, Kirikoshi H, Terasaki H and Shiokawa K: WNT2B2 mRNA, up-regulated in primary gastric cancer, is a positive regulator of the WNT- $\beta$-catenin-TCF signaling pathway. Biochem Biophys Res Commun 289: 1093-1098, 2001.

60. Jiang $X$ and Cong F: Novel regulation of Wnt signaling at the proximal membrane level. Trends Biochem Sci 41: 773-783, 2016.

61. Milne AN, Carneiro F, O'Morain C and Offerhaus GJ: Nature meets nurture: Molecular genetics of gastric cancer. Hum Genet 126: 615-628, 2009.

62. Leodolter A, Alonso S, González B, Ebert MP, Vieth M, Röcken C, Wex T, Peitz U, Malfertheiner P and Perucho M: Somatic DNA hypomethylation in $H$. pylori-associated high-risk gastritis and gastric cancer: Enhanced somatic hypomethylation associates with advanced stage cancer. Clin Transl Gastroenterol 6: e85, 2015.

63. Ajani JA, Lee J, Sano T, Janjigian YY, Fan D and Song S: Gastric adenocarcinoma. Nat Rev Dis Primers 3: 17036, 2017.
64. Huh CW, Youn YH, Jung da H, Park JJ, Kim JH and Park H: Early attempts to eradicate Helicobacter pylori after endoscopic resection of gastric neoplasm significantly improve eradication success rates. PLoS One 11: e0162258, 2016.

65. Dang BN and Graham DY: Helicobacter pylori infection and antibiotic resistance: A WHO high priority? Nat Rev Gastroenterol Hepatol 14: 383-384, 2017.

66. Osumi H, Fujisaki J, Suganuma T, Horiuchi Y, Omae M, Yoshio T, Ishiyama A, Tsuchida T and Miki K: A significant increase in the pepsinogen I/II ratio is a reliable biomarker for successful Helicobacter pylori eradication. PLoS One 12: e0183980, 2017.

67. Seta T, Takahashi Y, Noguchi Y, Shikata S, Sakai T, Sakai K, Yamashita Y and Nakayama T: Effectiveness of Helicobacter pylori eradication in the prevention of primary gastric cancer in healthy asymptomatic people: A systematic review and meta-analysis comparing risk ratio with risk difference. PLoS One 12: e0183321, 2017.

68. Smyth MJ, Ngiow SF, Ribas A and Teng MW: Combination cancer immunotherapies tailored to the tumour microenvironment. Nat Rev Clin Oncol 13: 143-158, 2016.

69. Arzumanyan A, Reis HM and Feitelson MA: Pathogenic mechanisms in HBV- and HCV-associated hepatocellular carcinoma. Nat Rev Cancer 13: 123-135, 2013.

70. Touboul T, Chen S, To CC, Mora-Castilla S, Sabatini K, Tukey RH and Laurent LC: Stage-specific regulation of the WNT/ $\beta$-catenin pathway enhances differentiation of hESCs into hepatocytes. J Hepatol 64: 1315-1326, 2016.

71. Planas-Paz L, Orsini V, Boulter L, Calabrese D, Pikiolek M, Nigsch F, Xie Y, Roma G, Donovan A, Marti P, et al: The RSPO-LGR4/5-ZNRF3/RNF43 module controls liver zonation and size. Nat Cell Biol 18: 467-479, 2016.

72. Okabe H, Yang J, Sylakowski K, Yovchev M, Miyagawa Y, Nagarajan S, Chikina M, Thompson M, Oertel M, Baba H, et al: Wnt signaling regulates hepatobiliary repair following cholestatic liver injury in mice. Hepatology 64: 1652-1666, 2016.

73. Li J, Hu SB, Wang LY, Zhang X, Zhou X, Yang B, Li JH, Xiong J, Liu N, Li Y, et al: Autophagy-dependent generation of Axin2 ${ }^{+}$ cancer stem-like cells promotes hepatocarcinogenesis in liver cirrhosis. Oncogene 36: 6725-6737, 2017.

74. Kuijk EW, Rasmussen S, Blokzijl F, Huch M, Gehart H, Toonen P, Begthel H, Clevers H, Geurts AM and Cuppen E: Generation and characterization of rat liver stem cell lines and their engraftment in a rat model of liver failure. Sci Rep 6: 22154, 2016.

75. Yin X, Yi H, Wang L, Wu W, Wu X and Yu L: RSPOs facilitated HSC activation and promoted hepatic fibrogenesis. Oncotarget 7: 63767-63778, 2016.

76. Tokunaga Y, Osawa Y, Ohtsuki T, Hayashi Y, Yamaji K, Yamane D, Hara M, Munekata K, Tsukiyama-Kohara K, Hishima $\mathrm{T}$, et al: Selective inhibitor of $\mathrm{Wnt} / \beta$-catenin/CBP signaling ameliorates hepatitis $C$ virus-induced liver fibrosis in mouse model. Sci Rep 7: 325, 2017.

77. Tao J, Xu E, Zhao Y, Singh S, Li X, Couchy G, Chen X, Zucman-Rossi J, Chikina M and Monga SP: Modeling a human hepatocellular carcinoma subset in mice through coexpression of Met and point-mutant $\beta$-catenin. Hepatology 64: 1587-1605, 2016.

78. Zhang J, Lai W, Li Q, Yu Y, Jin J, Guo W, Zhou X, Liu X and Wang Y: A novel oncolytic adenovirus targeting Wnt signaling effectively inhibits cancer-stem like cell growth via metastasis, apoptosis and autophagy in HCC models. Biochem Biophys Res Commun 491: 469-477, 2017.

79. Lamb YN: Glecaprevir/pibrentasvir: First global approval. Drugs 77: 1797-1804, 2017.

80. Nehra V, Rizza SA and Temesgen Z: Sofosbuvir/velpatasvir fixed-dose combination for the treatment of chronic hepatitis $C$ virus infection. Drugs Today (Barc) 53: 177-189, 2017.

81. Conti F, Buonfiglioli F, Scuteri A, Crespi C, Bolondi L, Caraceni P, Foschi FG, Lenzi M, Mazzella G, Verucchi G, et al: Early occurrence and recurrence of hepatocellular carcinoma in HCV-related cirrhosis treated with direct-acting antivirals. J Hepatol 65: 727-733, 2016.

82. Reig M, Mariño Z, Perelló C, Iñarrairaegui M, Ribeiro A, Lens S, Díaz A, Vilana R, Darnell A, Varela M, et al: Unexpected high rate of early tumor recurrence in patients with HCV-related HCC undergoing interferon-free therapy. J Hepatol 65: 719-726, 2016.

83. Kobayashi M, Suzuki F, Fujiyama S, Kawamura Y, Sezaki H, Hosaka T, Akuta N, Suzuki Y, Saitoh S, Arase Y, et al: Sustained virologic response by direct antiviral agents reduces the incidence of hepatocellular carcinoma in patients with $\mathrm{HCV}$ infection. J Med Virol 89: 476-483, 2017. 
84. Selman M, López-Otín C and Pardo A: Age-driven developmental drift in the pathogenesis of idiopathic pulmonary fibrosis. Eur Respir J 48: 538-552, 2016.

85. Knudsen L, Ruppert $\mathrm{C}$ and Ochs M: Tissue remodelling in pulmonary fibrosis. Cell Tissue Res 367: 607-626, 2017.

86. Cao Z, Lis R, Ginsberg M, Chavez D, Shido K, Rabbany SY, Fong GH, Sakmar TP, Rafii S and Ding BS: Targeting of the pulmonary capillary vascular niche promotes lung alveolar repair and ameliorates fibrosis. Nat Med 22: 154-162, 2016.

87. Andersson-Sjöland A, Karlsson JC and Rydell-Törmänen K: ROS-induced endothelial stress contributes to pulmonary fibrosis through pericytes and Wnt signaling. Lab Invest 96 : 206-217, 2016

88. Misharin AV, Morales-Nebreda L, Reyfman PA, Cuda CM, Walter JM, McQuattie-Pimentel AC, Chen CI, Anekalla KR, Joshi N, Williams KJN, et al: Monocyte-derived alveolar macrophages drive lung fibrosis and persist in the lung over the life span. J Exp Med 214: 2387-2404, 2017.

89. Henderson WR Jr, Chi EY, Ye X, Nguyen C, Tien YT, Zhou B, Borok Z, Knight DA and Kahn M: Inhibition of Wnt/ $\beta$-catenin/CREB binding protein (CBP) signaling reverses pulmonary fibrosis. Proc Natl Acad Sci USA 107: 14309-14314, 2010.

90. Chen X, Shi C, Meng X, Zhang K, Li X, Wang C, Xiang Z, Hu K and Han $X$ : Inhibition of Wnt $/ \beta$-catenin signaling suppresses bleomycin-induced pulmonary fibrosis by attenuating the expression of TGF- $\beta 1$ and FGF-2. Exp Mol Pathol 101: 22-30, 2016.

91. Campbell JD, Alexandrov A, Kim J, Wala J, Berger AH, Pedamallu CS, Shukla SA, Guo G, Brooks AN, Murray BA, et al: Distinct patterns of somatic genome alterations in lung adenocarcinomas and squamous cell carcinomas. Nat Genet 48 607-616, 2016.

92. Tammela T, Sanchez-Rivera FJ, Cetinbas NM, Wu K, Joshi NS Helenius K, Park Y, Azimi R, Kerper NR, Wesselhoeft RA, et al A Wnt-producing niche drives proliferative potential and progression in lung adenocarcinoma. Nature 545: 355-359, 2017.

93. Chartier C, Raval J, Axelrod F, Bond C, Cain J, Dee-Hoskins C, Ma S, Fischer MM, Shah J, Wei J, et al: Therapeutic targeting of tumor-derived R-Spondin attenuates $\beta$-catenin signaling and tumorigenesis in multiple cancer types. Cancer Res 76: 713-723, 2016

94. Yang Y, Shen J, He J, He J and Jiang G: A meta-analysis of abnormal $\beta$-catenin immunohistochemical expression as a prognostic factor in lung cancer: Location is more important. Clin Transl Oncol 18: 685-692, 2016.

95. Jin J, Zhan P, Katoh M, Kobayashi SS, Phan K, Qian H, Li H Wang X, Wang X and Song Y; Written on behalf of the AME Lung Cancer Collaborative Group: Prognostic significance of $\beta$-catenin expression in patients with non-small cell lung cancer: A meta-analysis. Transl Lung Cancer Res 6: 97-108, 2017.

96. Mano H: ALKoma: A cancer subtype with a shared target. Cancer Discov 2: 495-502, 2012.

97. Seo JS, Ju YS, Lee WC, Shin JY, Lee JK, Bleazard T, Lee J, Jung YJ, Kim JO, Shin JY, et al: The transcriptional landscape and mutational profile of lung adenocarcinoma. Genome Res 22 2109-2119, 2012.

98. Hirsch FR, Suda K, Wiens J and Bunn PA Jr: New and emerging targeted treatments in advanced non-small-cell lung cancer. Lancet 388: 1012-1024, 2016.

99. Katoh M: Therapeutics targeting FGF signaling network in human diseases. Trends Pharmacol Sci 37: 1081-1096, 2016.

100. Gurney A, Axelrod F, Bond CJ, Cain J, Chartier C, Donigan L, Fischer M, Chaudhari A, Ji M, Kapoun AM, et al: Wnt pathway inhibition via the targeting of Frizzled receptors results in decreased growth and tumorigenicity of human tumors. Proc Natl Acad Sci USA 109: 11717-11722, 2012.

101. Steinhart Z, Pavlovic Z, Chandrashekhar M, Hart T, Wang X, Zhang X, Robitaille M, Brown KR, Jaksani S, Overmeer R, et al: Genome-wide CRISPR screens reveal a Wnt-FZD5 signaling circuit as a druggable vulnerability of RNF43-mutant pancreatic tumors. Nat Med 23: 60-68, 2017.

102. Bendell J, Eckhardt GS, Hochster HS, Morris VK, Strickler J, Kapoun AM, Wang M, Xu L, McGuire K, Dupont J, et al: Initial results from a phase $1 \mathrm{a} / \mathrm{b}$ study of OMP-131R 10, a first-in-class anti-RSPO3 antibody, in advanced solid tumors and previously treated metastatic colorectal cancer (CRC). Eur J Cancer 69 (Suppl 1): S29-S30, 2016.
103. Le PN, McDermott JD and Jimeno A: Targeting the Wnt pathway in human cancers: Therapeutic targeting with a focus on OMP-54F28. Pharmacol Ther 146: 1-11, 2015.

104. Madan B, Ke Z, Harmston N, Ho SY, Frois AO, Alam J, Jeyaraj DA, Pendharkar V, Ghosh K, Virshup IH, et al: Wnt addiction of genetically defined cancers reversed by PORCN inhibition. Oncogene 35: 2197-2207, 2016.

105. Chen CW, Beyer C, Liu J, Maier C, Li C, Trinh-Minh T, Xu X, Cole $\mathrm{SH}, \mathrm{Hsieh} \mathrm{MH}, \mathrm{Ng} \mathrm{N}$, et al: Pharmacological inhibition of porcupine induces regression of experimental skin fibrosis by targeting Wnt signalling. Ann Rheum Dis 76: 773-778, 2017.

106. Blyszczuk P, Müller-Edenborn B, Valenta T, Osto E, Stellato M, Behnke S, Glatz K, Basler K, Lüscher TF, Distler O, et al: Transforming growth factor- $\beta$-dependent Wnt secretion controls myofibroblast formation and myocardial fibrosis progression in experimental autoimmune myocarditis. Eur Heart J 38: 1413-1425, 2017

107. Liu J, Pan S, Hsieh MH, Ng N, Sun F, Wang T, Kasibhatla S, Schuller AG, Li AG, Cheng D, et al: Targeting Wnt-driven cancer through the inhibition of Porcupine by LGK974. Proc Natl Acad Sci USA 110: 20224-20229, 2013.

108. Quackenbush KS, Bagby S, Tai WM, Messersmith WA, Schreiber A, Greene J, Kim J, Wang G, Purkey A, Pitts TM, et al: The novel tankyrase inhibitor (AZ1366) enhances irinotecan activity in tumors that exhibit elevated tankyrase and irinotecan resistance. Oncotarget 7: 28273-28285, 2016.

109. Lau T, Chan E, Callow M, Waaler J, Boggs J, Blake RA, Magnuson S, Sambrone A, Schutten M, Firestein R, et al: A novel tankyrase small-molecule inhibitor suppresses APC mutation-driven colorectal tumor growth. Cancer Res 73: 3132-3144, 2013

110. Shultz MD, Cheung AK, Kirby CA, Firestone B, Fan J, Chen CH, Chen Z, Chin DN, Dipietro L, Fazal A, et al: Identification of NVP-TNKS656: The use of structure-efficiency relationships to generate a highly potent, selective, and orally active tankyrase inhibitor. J Med Chem 56: 6495-6511, 2013.

111. Huang SM, Mishina YM, Liu S, Cheung A, Stegmeier F, Michaud GA, Charlat O, Wiellette E, Zhang Y, Wiessner S, et al: Tankyrase inhibition stabilizes Axin and antagonizes Wnt signalling. Nature 461: 614-620, 2009.

112. Trautmann M, Sievers E, Aretz S, Kindler D, Michels S, Friedrichs N, Renner M, Kirfel J, Steiner S, Huss S, et al: SS18-SSX fusion protein-induced $\mathrm{Wnt} / \beta$-catenin signaling is a therapeutic target in synovial sarcoma. Oncogene 33: 5006-5016, 2014

113. Jang GB, Hong IS, Kim RJ, Lee SY, Park SJ, Lee ES, Park JH, Yun $\mathrm{CH}$, Chung JU, Lee KJ, et al: Wnt/ $\beta$-catenin small-molecule inhibitor CWP232228 preferentially inhibits the growth of breast cancer stem-like cells. Cancer Res 75: 1691-1702, 2015.

114. Yamada K, Hori Y, Yamaguchi A, Matsuki M, Tsukamoto S, Yokoi A, Semba T, Ozawa Y, Inoue S, Yamamoto Y, et al: Abstract 5177: E7386: First-in-class orally active CBP/ $\beta$-catenin modulator as an anticancer agent. In: Proceedings of the American Association for Cancer Research Annual Meeting 2017; 2017 Apr 1-5; Washington, DC. Philadelphia: AACR; Cancer Res 77 (Suppl 13): 5177, 2017.

115. Fang L, Zhu Q, Neuenschwander M, Specker E, Wulf-Goldenberg A, Weis WI, von Kries JP and Birchmeier W: A small-molecule antagonist of the $\beta$-catenin/TCF4 interaction blocks the self-renewal of cancer stem cells and suppresses tumorigenesis. Cancer Res 76: 891-901, 2016.

116. Zhou H, Mak PY, Mu H, Mak DH, Zeng Z, Cortes J, Liu Q, Andreeff $M$ and Carter BZ: Combined inhibition of $\beta$-catenin and Bcr-Abl synergistically targets tyrosine kinase inhibitor-resistant blast crisis chronic myeloid leukemia blasts and progenitors in vitro and in vivo. Leukemia 31: 2065-2074, 2017

117. Katoh $\mathrm{M}$ and Katoh $\mathrm{M}$ : Identification and characterization of JMJD2 family genes in silico. Int J Oncol 24: 1623-1628, 2004.

118. Berry WL and Janknecht R: KDM4/JMJD2 histone demethylases: Epigenetic regulators in cancer cells. Cancer Res 73: 2936-2942, 2013.

119. Kim TD, Fuchs JR, Schwartz E, Abdelhamid D, Etter J, Berry WL, Li C, Ihnat MA, Li PK and Janknecht R: Pro-growth role of the JMJD2C histone demethylase in HCT-116 colon cancer cells and identification of curcuminoids as JMJD2 inhibitors. Am J Transl Res 6: 236-247, 2014.

120. Pedersen MT, Kooistra SM, Radzisheuskaya A, Laugesen A, Johansen JV, Hayward DG, Nilsson J, Agger K and Helin K: Continual removal of H3K9 promoter methylation by Jmjd2 demethylases is vital for ESC self-renewal and early development. EMBO J 35: 1550-1564, 2016. 
121. Tomaz RA, Harman JL, Karimlou D, Weavers L, Fritsch L, Bou-Kheir T, Bell E, Del Valle Torres I, Niakan KK, Fisher C, et al: Jmjd2c facilitates the assembly of essential enhancer-protein complexes at the onset of embryonic stem cell differentiation. Development 144: 567-579, 2017.

122. Lepourcelet M, Chen YN, France DS, Wang H, Crews P, Petersen F, Bruseo C, Wood AW and Shivdasani RA: Small-molecule antagonists of the oncogenic Tcf $/ \beta$-catenin protein complex. Cancer Cell 5: 91-102, 2004.

123. Franci G, Sarno F, Nebbioso A and Altucci L: Identification and characterization of PKF118-310 as a KDM4A inhibitor. Epigenetics 12: 198-205, 2017.

124. Wei W, Chua MS, Grepper S and So S: Small molecule antagonists of Tcf4/ $\beta$-catenin complex inhibit the growth of HCC cells in vitro and in vivo. Int J Cancer 126: 2426-2436, 2010

125. Hallett RM, Kondratyev MK, Giacomelli AO, Nixon AML, Girgis-Gabardo A, Ilieva D and Hassell JA: Small molecule antagonists of the Wnt/ $\beta$-catenin signaling pathway target breast tumor-initiating cells in a Her2/Neu mouse model of breast cancer. PLoS One 7: e33976, 2012.

126. Beyer C, Reichert H, Akan H, Mallano T, Schramm A, Dees C, Palumbo-Zerr K, Lin NY, Distler A, Gelse K, et al: Blockade of canonical Wnt signalling ameliorates experimental dermal fibrosis. Ann Rheum Dis 72: 1255-1258, 2013

127. Katoh M: Mutation spectra of histone methyltransferases with canonical SET domains and EZH2-targeted therapy. Epigenomics 8: 285-305, 2016.

128. Chen JF, Luo X, Xiang LS, Li HT, Zha L, Li N, He JM, Xie GF, Xie X and Liang HJ: EZH2 promotes colorectal cancer stem-like cell expansion by activating p21cip1-Wnt/ $\beta$-catenin signaling. Oncotarget 7: 41540-41558, 2016

129. Huang M, Chen C, Geng J, Han D, Wang T, Xie T, Wang L, Wang $Y$, Wang $C$, Lei $Z$ and Chu $X$ : Targeting KDM1A attenuates $\mathrm{Wnt} / \beta$-catenin signaling pathway to eliminate sorafenib-resistant stem-like cells in hepatocellular carcinoma. Cancer Lett 398: 12-21, 2017.

130. Jin Y, Zhou J, Xu F, Jin B, Cui L, Wang Y, Du X, Li J, Li P, Ren R and Pan J: Targeting methyltransferase PRMT5 eliminates leukemia stem cells in chronic myelogenous leukemia. J Clin Invest 126: 3961-3980, 2016.

131. Feinberg AP, Koldobskiy MA and Göndör A: Epigenetic modulators, modifiers and mediators in cancer aetiology and progression. Nat Rev Genet 17: 284-299, 2016.

132. Morera L, Lübbert $M$ and Jung M: Targeting histone methyltransferases and demethylases in clinical trials for cancer therapy. Clin Epigenetics 8: 57, 2016.

133. Allis CD and Jenuwein T: The molecular hallmarks of epigenetic control. Nat Rev Genet 17: 487-500, 2016.

134. Jones PA, Issa JP and Baylin S: Targeting the cancer epigenome for therapy. Nat Rev Genet 17: 630-641, 2016.

135. Kim S, Xu X, Hecht A and Boyer TG: Mediator is a transducer of Wnt/beta-catenin signaling. J Biol Chem 281: 14066-14075, 2006

136. Hnisz D, Abraham BJ, Lee TI, Lau A, Saint-André V, Sigova AA Hoke HA and Young RA: Super-enhancers in the control of cell identity and disease. Cell 155: 934-947, 2013.

137. Yin JW and Wang G: The Mediator complex: A master coordinator of transcription and cell lineage development. Development 141: 977-987, 2014.

138. Mallinger A, Crumpler S, Pichowicz M, Waalboer D, Stubbs M, Adeniji-Popoola O, Wood B, Smith E, Thai C, Henley AT, et al: Discovery of potent, orally bioavailable, small-molecule inhibitors of WNT signaling from a cell-based pathway screen. J Med Chem 58: 1717-1735, 2015

139. Dale T, Clarke PA, Esdar C, Waalboer D, Adeniji-Popoola O, Ortiz-Ruiz MJ, Mallinger A, Samant RS, Czodrowski P, Musil D, et al: A selective chemical probe for exploring the role of CDK8 and CDK19 in human disease. Nat Chem Biol 11: 973-980, 2015.

140. Pelish HE, Liau BB, Nitulescu II, Tangpeerachaikul A, Poss ZC, Da Silva DH, Caruso BT, Arefolov A, Fadeyi O, Christie AL, et al: Mediator kinase inhibition further activates super-enhancer-associated genes in AML. Nature 526: 273-276, 2015.

141. Poss ZC, Ebmeier CC, Odell AT, Tangpeerachaikul A, Lee T, Pelish HE, Shair MD, Dowell RD, Old WM and Taatjes DJ: Identification of Mediator kinase substrates in human cells using cortistatin A and quantitative phosphoproteomics. Cell Rep 15: 436-450, 2016.
142. Todaro M, Gaggianesi M, Catalano V, Benfante A, Iovino F, Biffoni M, Apuzzo T, Sperduti I, Volpe S, Cocorullo G, et al: $\mathrm{CD} 44 \mathrm{v} 6$ is a marker of constitutive and reprogrammed cancer stem cells driving colon cancer metastasis. Cell Stem Cell 14: 342-356, 2014

143. Schmitt M, Metzger M, Gradl D, Davidson G and Orian-Rousseau V: CD44 functions in Wnt signaling by regulating LRP6 localization and activation. Cell Death Differ 22: 677-689, 2015

144. Jiang WG, Sanders AJ, Katoh M, Ungefroren H, Gieseler F, Prince M, Thompson SK, Zollo M, Spano D, Dhawan P, et al: Tissue invasion and metastasis: Molecular, biological and clinical perspectives. Semin Cancer Biol 35 (Suppl): S244-S275, 2015.

145. Hira VVV, Van Noorden CJF, Carraway HE, Maciejewski JP and Molenaar RJ: Novel therapeutic strategies to target leukemic cells that hijack compartmentalized continuous hematopoietic stem cell niches. Biochim Biophys Acta 1868: 183-198, 2017.

146. Vincan E, Flanagan DJ, Pouliot N, Brabletz T and Spaderna S: Variable FZD7 expression in colorectal cancers indicates regulation by the tumour microenvironment. Dev Dyn 239: 311-317, 2010.

147. Simmons GE Jr, Pandey S, Nedeljkovic-Kurepa A, Saxena M, Wang A and Pruitt K: Frizzled 7 expression is positively regulated by SIRT1 and $\beta$-catenin in breast cancer cells. PLoS One 9: e98861, 2014.

148. Qiu X, Jiao J, Li Y and Tian T: Overexpression of FZD7 promotes glioma cell proliferation by upregulating TAZ. Oncotarget 7: 85987-85999, 2016.

149. Carmon KS, Gong X, Yi J, Wu L, Thomas A, Moore CM, Masuho I, Timson DJ, Martemyanov KA and Liu QJ: LGR5 receptor promotes cell-cell adhesion in stem cells and colon cancer cells via the IQGAP1-Rac1 pathway. J Biol Chem 292: 14989-15001, 2017.

150. Ayyar BV, Arora S and O'Kennedy R: Coming-of-age of antibodies in cancer therapeutics. Trends Pharmacol Sci 37: 1009-1028, 2016.

151. Beck A, Goetsch L, Dumontet C and Corvaïa N: Strategies and challenges for the next generation of antibody-drug conjugates. Nat Rev Drug Discov 16: 315-337, 2017.

152. Kontermann RE and Brinkmann U: Bispecific antibodies. Drug Discov Today 20: 838-847, 2015.

153. Stadler CR, Bähr-Mahmud H, Celik L, Hebich B, Roth AS, Roth RP, Karikó K, Türeci O and Sahin Y: Elimination of large tumors in mice by mRNA-encoded bispecific antibodies. Nat Med 23: 815-817, 2017.

154. Jackson HJ, Rafiq S and Brentjens RJ: Driving CAR T-cells forward. Nat Rev Clin Oncol 13: 370-383, 2016.

155. Dai H, Wang Y, Lu X and Han W: Chimeric antigen receptors modified T-cells for cancer therapy. J Natl Cancer Inst 108: djv439, 2016

156. Casucci M, Nicolis di Robilant B, Falcone L, Camisa B, Norelli M, Genovese P, Gentner B, Gullotta F, Ponzoni M, Bernardi M, et al: CD44v6-targeted T cells mediate potent antitumor effects against acute myeloid leukemia and multiple myeloma. Blood 122: 3461-3472, 2013.

157. Junttila MR, Mao W, Wang X, Wang BE, Pham $T$, Flygare J, Yu SF, Yee S, Goldenberg D, Fields C, et al: Targeting LGR $5^{+}$cells with an antibody-drug conjugate for the treatment of colon cancer. Sci Transl Med 7: 314ra186, 2015.

158. Gong X, Azhdarinia A, Ghosh SC, Xiong W, An Z, Liu Q and Carmon KS: LGR5-targeted antibody-drug conjugate eradicates gastrointestinal tumors and prevents recurrence. Mol Cancer Ther 15: 1580-1590, 2016.

159. Riechelmann H, Sauter A, Golze W, Hanft G, Schroen C, Hoermann K, Erhardt T and Gronau S: Phase I trial with the CD44v6-targeting immunoconjugate bivatuzumab mertansine in head and neck squamous cell carcinoma. Oral Oncol 44: 823-829, 2008.

160. Al-Rawi V, Laeufer T, Glocker K, Heneka $\mathrm{Y}$ and Matzke-Ogi A: Abstract 4911: Allosteric inhibition of the receptor tyrosine kinases c-MET, RON and VEGFR-2 via the co-receptor CD44v6 by the novel compound AMC303. In: Proceedings of the American Association for Cancer Research Annual Meeting 2017; Apr 1-5, 2017; Washington, DC. Philadelphia: AACR; Cancer Res 77 (Suppl 13): 4911, 2017. 
161. Inglis DJ, Beaumont DM and Lavranos TC: Abstract 4695: Targeting the LGR5 complex with BNC101 to improve checkpoint inhibitor therapy in colorectal cancer. In: Proceedings of the American Association for Cancer Research Annual Meeting 2017; Apr 1-5, 2017; Washington, DC. Philadelphia: AACR; Cancer Res 77 (Suppl 13): 4695, 2017.

162. Katoh M: The integration of genomics testing and functional proteomics in the era of personalized medicine. Expert Rev Proteomics 14: 1055-1058, 2017.

163. Frampton GM, Fichtenholtz A, Otto GA, Wang K, Downing SR, He J, Schnall-Levin M, White J, Sanford EM, An P, et al: Development and validation of a clinical cancer genomic profiling test based on massively parallel DNA sequencing. Nat Biotechnol 31: 1023-1031, 2013.

164. Hovelson DH, McDaniel AS, Cani AK, Johnson B, Rhodes K, Williams PD, Bandla S, Bien G, Choppa P, Hyland F, et al: Development and validation of a scalable next-generation sequencing system for assessing relevant somatic variants in solid tumors. Neoplasia 17: 385-399, 2015.

165. Friedman AA, Letai A, Fisher DE and Flaherty KT: Precision medicine for cancer with next-generation functional diagnostics. Nat Rev Cancer 15: 747-756, 2015.
166. Pauli C, Hopkins BD, Prandi D, Shaw R, Fedrizzi T, Sboner A, Sailer V, Augello M, Puca L, Rosati R, et al: Personalized in vitro and in vivo cancer models to guide precision medicine. Cancer Discov 7: 462-477, 2017.

167. Whorehouses D and Caldas C: Of mice and men: Patient-derived xenografts in cancer medicine. Ann Oncol 28: 2330-2331, 2017.

168. Singal AG and El-Serag HB: Hepatocellular carcinoma from epidemiology to prevention: Translating knowledge into practice. Clin Gastroenterol Hepatol 13: 2140-2151, 2015.

169. Zeng M, Mao XH, Li JX, Tong WD, Wang B, Zhang YJ, Guo G, Zhao ZJ,Li L, Wu DL, et al: Efficacy, safety, and immunogenicity of an oral recombinant Helicobacter pylori vaccine in children in China: A randomised, double-blind, placebo-controlled, phase 3 trial. Lancet 386: 1457-1464, 2015.

(c) (i) $(-)$ This work is licensed under a Creative Commons Attribution-NonCommercial-NoDerivatives 4.0 International (CC BY-NC-ND 4.0) License. 